\title{
街路環境整備事業の計画策定段階における協議過程の可視化方法に関する研究 韓国の大邱市東城路公共デザイン改善事業を事例として \\ A METHOD FOR THE VISUALIZATION OF THE DELIBERATIVE PROCESS IN URBAN ENVIRONMENT IMPROVEMENT PROJECT
}

Focused on the Dongseong-ro public design improvement project in Dae-gu, Korea

\author{
全 ソンイ*
}

\section{Songyi JEON}

\begin{abstract}
The present study develops a new methodology to visualize the interactions between stakeholders during consensus building processes. The research takes as an example the urban environment improvement master plan consultation process for a commercial street in Dongseong-ro, Dae-gu city, Korea.

As a result, the following points were clarified:

1. For some topics, the plan was changed after modifications were requested.

2. Prior to changes in the Mater Plan, Master Architect(MA) made the main proposal. Then, after the main modifications, adjustments were made.

3. In order to support the consensus process, it is important that Government and the Promotion Committee understand the diverse issues, and that countermeasures are request to the MA.
\end{abstract}

\section{Keywords : Dongseong-ro Public Design Improvement Project, Planning Process, Debate, Coordination, \\ Consensus Building \\ 東城路公共デザイン改善事業, 計画策定過程, 討議, 調整, 合意形成}

1. はじめに

\section{1-1. 研究の背景と目的}

今日、日本と同様に韓国においても既成市街地の衰退を克服する ために、街路環境改善を通じて公共性と快適性を創出し、都市の活 性化を図る都市再生事業が推進されている注1)。しかし公共街路事業 には多様な主体の利害関係が絡んでおり、これによって異なる価值 観を持つ利害関係者の葛藤が避けられない。このことから、計画の 策定段階から多様な主体が参加し、意見交換することができる協議 の場を設けて、十分な討議が行われること、さらに個別テーマの調 整過程と、その討議過程で得られた結果を意思決定に結びつけるこ とが必要である 1)。また、このような討議の過程において、参加主 体間にどのような葛藤があったのか、どのような要素で合意形成に 至ったのかを可視化し、共有することは、今後の都市再生事業で発 生する問題を事前に認知し、解決することが期待される。

本研究では以上を踏まえて、推進委員会の代表者による討議に基 づく街路環境整備事業の成功事例である韓国の東城路公共デザイン 改善事業を分析対象として、街路環境整備事業のマスタープラン注 2)の策定段階においてどのような意見調整の過程を経て、合意形成
に至ったのかを、会議録に基づいた質的分析法により可視化する方 法を開発し、その協議過程を明らかにすることを目的とする。

\section{1-2. 既往研究と本稿の位置づけ}

合意形成の過程を分析する資料として事業の会議録に基づいた既 往研究には、マスターアーキテクト方式のキャンパスデザインにお いて、マスターアーキテクトとブロックアーキテクトが環境設計プ ロセスを展開する際に発生したデザインに対する意見の相違解決を モデル化し、合意形成手法を提示した北尾 ${ }^{2)}$ 、民間企業が主導する 都市再開発事業の計画決定段階における関係者間の応答構造を分析

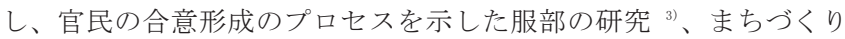
小集団の会議から構成員の発言のターン(発話の単位)に着目し、そ の割合の変化点をシークェンスの区切りとして使用した島田の研究 4)などが、事業の会議録による協議の内容を扱っている。

それらの研究はプロセスの中で参加主体間の対応関係を合意形成 の手法として扱っているが、街路環境改善事業の参加主体間による 議論の変化プロセスを表現する方法は開発されていない。

本研究はマスターアーキテクト(Master Architect、以下 MA) と推 進委員会の代表者による韓国の街路環境整備事業を事例とし、マス

\footnotetext{
$*$ 早稲田大学大学院創造理工学研究科建築学専攻 博士課程
} Doctoral Course, Grad. Student, Dept. of Architecture, Faculty of Science and Eng., Waseda Univ. 
タープランの策定段階における協議過程をダイヤグラムに示すこと で、マスタープランの策定過程を追体験でき、街路整備事業の関係 者に参考資料として共有することができる点で意義がある。

\section{2. 研究対象と方法}

\section{2-1. 研究対象の概要}

(1) 事業の概要

東城路公共デザイン改善事業は、文化体育観光部 (韓国の中央行政 署)の公共デザインモデル事業及び街路環境改善事業の一環として 進行され、文化体育観光部が国費の支援と事業全般の企画・調整を 行った。且つ、地域住民が参加する公共デザインを通じて、地域の アイデンティティと歴史性を反映する都市再生のモデルを提示し、 地域文化の活性化を図ることを目的としている ${ }^{5)}$ 。

その中で東城路公共デザイン改善事業は、2007 年 7 月に始まり、 2010 年 12 月に竣工され、専門家と公務員、市民代表と住民代表で 構成する推進委員会と、デザインを担当する MA、実務委員会注 ${ }^{3)}$ によって実行した、初の公共デザイン改善事業である注4)6)。

事業対象地の東城路は、大邱広域市の中区に位置し、大邱ウプソ ン(邑城)を崩して作られた道路の東の部分で、長い間大邱の商圈の 中心だった歩行者専用道路の中心商業街である。そこで行われた東 城路公共デザイン改善事業は昔の大邱城壁の跡を通じて、歴史的な アイデンティティを回復するデザインを主な概念とし、市民の歩行 権確保（邑城街の連結）、周辺領域との相互連携を通じたマスタープ ランの戦略を樹立した ${ }^{7)}$ 。

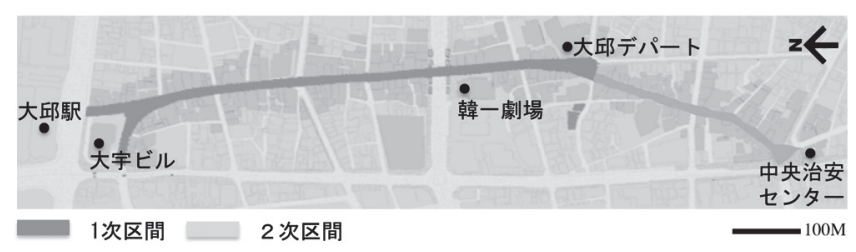

図 1 事業範囲注 5)

\section{(2) 事業の参加主体と体制}

利害関係者の意見の収斂と合意を導き出すための意思決定機構で ある推進委員会は、行政の一方的な構成ではなく、地域の専門家と 市民団体の代表が行政に提案した推進委員会の構成案に基づいて組 織された。事業の参加主体は図 2 に示すように、(1)行政支援推進団、 (2)推進委員会、(3)MA、(4)設計チーム、(5)民間協議会、(6)主管団体 (東 城路公共デザイン事務局) に区分される。

詳しく見ると、(1)行政支援推進団は、文化体育観光部、大邱市、 中区庁で構成されており、行政機関内の支援体制を構築し、事業の 企画・調整、予算確保及び支援、推進委員会の構成、関係機関との 協議や交流を担当した。(2)推進委員会は専門家、公務員注 6)、市民代 表、住民代表(商店経営者)で構成されており、事業推進の全過程の 意思決定機関として、MA の選定、マスタープランの承認、事業の 細部事項を樹立する機能を果たした。(3)MA はデザインの概念を提 示し、推進委員会と協議してマスタープランを計画した。また、(4) 設計チームは空間、造景、デザイン、施設物分野の地域専門家で構 成され、MA と協力してマスタープランの細部計画及び実施設計を 行った。(5)民間協議会は商店街の住民代表、専門家、文化団体、市
民団体で構成され、事業推進の諮問及び意見を受け入れるように組 織された。(6)東城路公共デザインの事務局は、韓国建築家協会の大 邱支部が主催団体として選定され、事業と予算計画の作成、細部執 行や運営、結果報告と会計報告を引き受けた ${ }^{8)}$ 。

本論文では、行政支援推進団、推進委員、MA が揃って協議を進 めた推進委員会の会議を基に、マスタープランの策定段階における 協議過程を分析する。

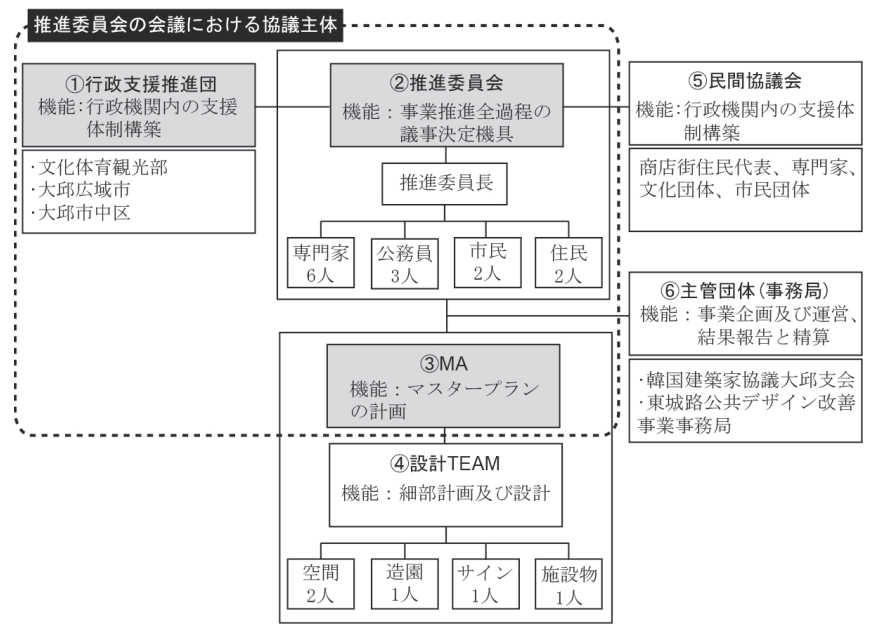

図 2 東城路公共デザイン改善事業の組織図注 7)

\section{2-2. 研究の方法}

本研究は推進委員会の会議録注 ${ }^{8)}$ を基に、マスタープランの策定段 階における、協議主体間の意見調整の過程を可視化する方法を提示 し、ダイヤグラムによる協議過程を解明するために、以下のように 行う(図 3)。

第一に、2007 年 7 月 26 日から 2009 年 4 月 3 日までの全 15 回 にわたって実施された東城路公共デザイン改善事業の進行過程や推 進委員会の討議内容を基に、マスタープランの策定段階を区分し、 その段階別に特徵を把握する (3 章)。

第二に、推進委員会の会議録から、調整の対象となる設計内容と 項目、調整行為を抽出し、参加主体間でどのようなやりとりがあっ たかを質的分析法による焦点的コーディングにより明らかにする。 これらを基に協議内容の可視化する方法を提案する (4 章)。

第三に、上記の方法を用いて、マスタープランの策定に向けた意 見調整の推移を可視化する。さらに、設計対象による議論展開の過 程を模式化し、意思決定のための主体間の関係特性を明らかにする (5 章)。

\section{3． マスタープランの策定までの過程}

本章では、図 4 のように、東城路公共デザイン改善事業のマスタ ープランの策定までの進行過程及び推進委員会の討議内容に基づき、 マスタープランの策定段階を区分し、その特徵を記述する注 9)。

\section{3-1. 第 1 段階 (整備事業の構想)}

MA と事業の全般に関する協議が行われ、整備事業を構想する段 階で、推進委員会の会議の第 1 回から第 6 回までが該当する。

まず円滑な事業推進のための推進委員会を組織し、主管団体を選 定した。また、行政と推進委員会が協議してMA を選定し、事業計 


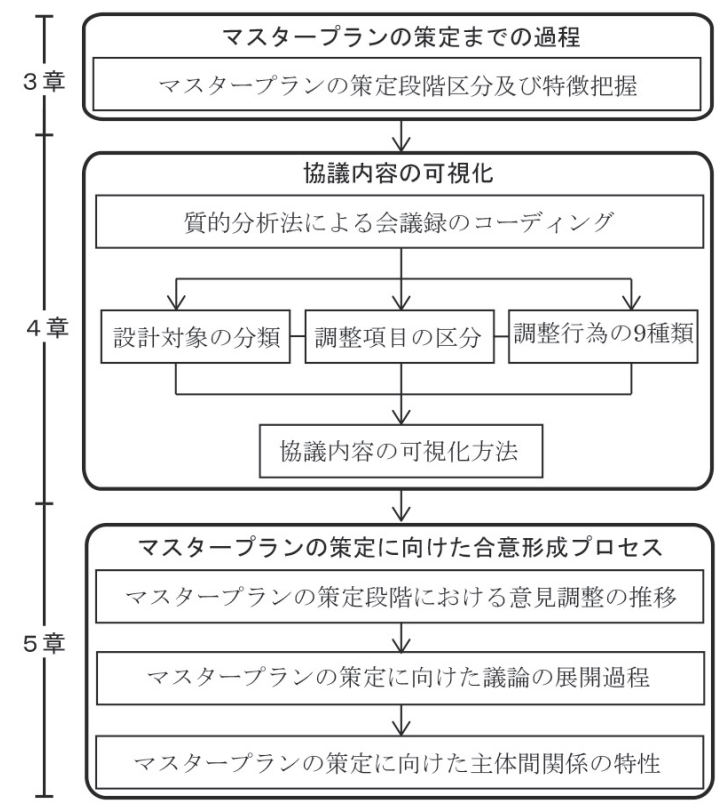

図 3 研究のフロー

画書及び予算案を検討した。その後、推進委員会で事業計画及び 予算案を確定し、MA と事業全般に関連する協議を進めた。計画素 案報告会では、MA が作業の方針やデザインの基本コンセプトを紹 介し、中間報告会では関連専門分野の推進委員らの意見を収斂し、 マスタープランの概念を提示し、調整した。

\section{3-2. 第 2 段階 (マスタープラン検討及びー部の承認)}

マスタープランの細部事項に関して論議が進められ、その計画内 容が承認された段階で、第 7 回のから第 9 回の推進委員会の会議ま でが該当する。

特にこの段階では、マスタープラン公共デザイン TF(Taskforce Team)協議会と関連部署の実務会議を開催し、マスタープランの細 部項目に対する効果的な実現に向けて関連機関の専門家らの協議が
行われ、施工上の問題点を把握した。また、市場報告会を開催し、 関連機関や東城路の商人、市民が事業の現況を共有する場を設けた。

推進委員会では、事業参加主体の現場調查やマスタープランの細 部事項に関寸る議論が行われ、この過程で、事業の日程や予算の一 部が変更された。そして最終報告会を経て、マスタープランの一部 が承認された。

\section{3-3． 第3 段階(マスタープラン変更及び承認)}

マスタープランの一部に変更事項があって、再論議した段階で、 第 10 回から第 12 回の推進委員会の会議までがここに該当する。

この段階では、マスタープランの変更事項及び設計の細部事項に 関する議論が行われ、マスタープランが最終的に承認された。一方、 市議会で緑化委員会が開催され、樹種に関する議論があり、横断歩 道の懇談会が行われ、市民の歩行権に関する論議が進められた。そ の後推進委員会で、樹種の選定と横断歩道の設置に対する議論が再 び重点的に行われた。このような過程を経て、マスタープランの実 施設計の内容がまとまった時期である。

\section{3-4．第 4 段階(マスタープラン完成)}

最後にマスタープランを検討し、設計をまとめた段階で、第 13 回から第 15 回の推進委員会の会議までが該当する。

実施設計が最終的に決まり、1 次区間の工事が開始された。また、 マスタープランの成果を報告する展示会と討論会が開催された。こ の時期の推進委員会では、事業後の管理のための運営委員会が提案 され、追加工事に関寸る協力要請や現場で発生した問題に対して解 決策を議論した。

\section{3-5. 小結}

第 1 段階では、MA がデザインの概念を提示し、各設計対象に対 して協議が行われた。第 2 段階では、MAのデザインに関する検討 が行われ、マスタープランが承認されたが、第 3 段階でマスタープ ランの変更要請があり、推進委員会は問題要因を把握し、計画変更 に対応した。第 4 段階は推進委員会から最終的に意見が収斂され、 設計案がまとまった。

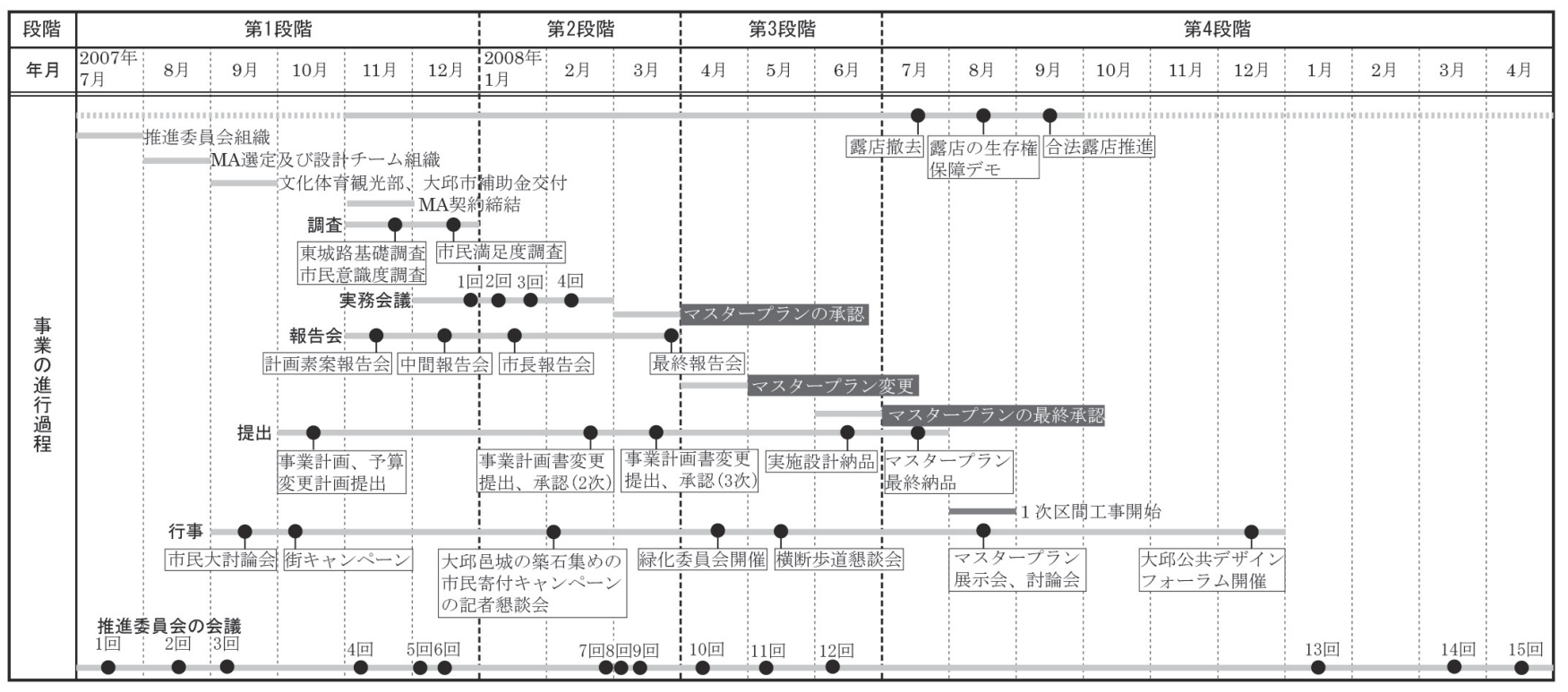

図 4 マスタープランの進行過程注 ${ }^{10)}$ 


\section{4. 協議内容の可視化}

本章では東城路公共デザイン改善事業の推進委員会の討議内容に 基づき、計画の策定までの全 15 回の推進委員会の会議のうち設計 案を協議した第 4 回、第 6 回、第 7 回、第 8 回、第 9 回、第 10 回、 第 11 回、第 12 回、第 15 回の協議内容に関する参加主体間の意見 調整の推移を可視化する方法を提案する。

\section{4-1. 質的データ分析による会議録のコーディング}

本研究は、東城路公共デザイン改善事業の推進委員会の会議録を 質的データとして活用し、マスタープラン策定に向けて誰が誰に対 して話をして、その協議内容は何かを分析するために、質的データ 分析法注 ${ }^{11}$ によるコーディングを行った(図 5)。

会議録のコーディングは、オリジナル文書の全体的な文脈による 設計内容に関する発言で区切り、セグメントの要約は文章セグメン トから一行ごとのコーディングを行う。それを基に誰が誰に対して どのような事を言っているのかを分類する。また、その話がどのよ うなテーマについて述べられているのかをセグメント要約内容から コードとして抽出し、一つのデータとして構成した ${ }^{9}$ 。

コード 1 はセグメントの要約により設計対象となる要素を表し、 コード 2 は協議の事項になる調整の課題を含んでいる。その内容を 表 2 のキーフレーズに当て、それに対応する調整項目として判断す る。さらに、発言や行為の背景に、どのような意図があるかを表 3 の行為の内容を基に調整行為に区分した。

\begin{tabular}{|c|c|c|c|c|c|c|c|c|c|}
\hline \multicolumn{7}{|c|}{ 文書セグメント } & \multicolumn{3}{|c|}{ セグメントの要約 } \\
\hline \multicolumn{7}{|c|}{$\begin{array}{ll}\text { 〈公務員の発言内容の原文〉 } & \vdots \\
\text { 高強度合成木材デッキに対寸る問題は } \\
\text { MAと中担当部署間にまだ解消で } \\
\text { きなかったそうた。特に、合成木材を } \\
\text { 使用したときの排水などが問題だ。 }\end{array}$} & \multicolumn{3}{|c|}{ ·高強度合成木材デッキの排水が問題だ。 } \\
\hline \multicolumn{7}{|c|}{$\begin{array}{l}\text { 〈MAの発言内容の原文〉 } \\
\text { 事業をしながら最も優先的に成就すべ } \\
\text { き目標は、東城路だけの色を探さなげ } \\
\text { ればならない。それで見付けたのが合 } \\
\text { 成木材デッキだ。 }\end{array}$} & \multicolumn{3}{|c|}{$\begin{array}{l}\text { ·東城路のアイデンティティと合成木材 } \\
\text { の関連性。 } \\
\Rightarrow\end{array}$} \\
\hline \multirow{2}{*}{ 順番 } & \multirow{2}{*}{ 日付 } & \multirow{2}{*}{$\begin{array}{l}\text { 先行 } \\
\text { 話者 }\end{array}$} & \multirow{2}{*}{\begin{tabular}{|l} 
調整 \\
方向 \\
\end{tabular}} & \multirow{2}{*}{$\begin{array}{l}\text { 後続 } \\
\text { 話者 } \\
\end{array}$} & \multirow{2}{*}{\begin{tabular}{|l|} 
調整 \\
行為 \\
\end{tabular}} & \multicolumn{3}{|c|}{ 項目及び要約内容 } & \multirow{2}{*}{ 回数 } \\
\hline & & & & & & コード1 & コード 2 & 要約内容 & \\
\hline 253 & $\begin{array}{l}2008 \\
0229\end{array}$ & 公務員 & $\triangleright$ & - & \begin{tabular}{|l|} 
問題 \\
指摘
\end{tabular} & 合成木材 & $\begin{array}{l}\text { 合成木材 } \\
\text { デッキの } \\
\text { 排水 }\end{array}$ & $\begin{array}{l}\text { 合成木材デッキの排水 } \\
\text { が問題だ。 }\end{array}$ & 7回 \\
\hline \multicolumn{10}{|c|}{ 省略 } \\
\hline 256 & $\begin{array}{l}2008 \\
0229\end{array}$ & - & $\triangleleft$ & MA & 説明 & 合成木材 & $\begin{array}{l}\text { 舗装材料 } \\
\text { 選定 }\end{array}$ & {$\left[\begin{array}{l}\text { 東城路のアイデンティ } \\
\text { ティと合成木材の関連 } \\
\text { 性。 }\end{array}\right.$} & 7 回 \\
\hline
\end{tabular}

図 5 歩道舗装に関するコーディングの例

\section{4-2. 街路整備の設計対象}

ここでどのような設計対象を中心に協議が進行したかを分析する ために、まず東城路公共デザイン改善事業の報告書により分野別の 設計内容を踏まえて、基本分類を行った。また、その区分に含まれ る設計要素は会議録のコーディングのセグメントの要約から構成要 素を抽出し、本論での分類に整理した。それを基に、協議の対象と なる項目は、「歩道舗装」「横断歩道」、「露店」、「広場」「建築物」、 「街路樹」、「サイン」「施設物」に分ける（表 1 ）。

\section{4-3. 調整項目の区分}

各会議で話し合った主な調整の内容を分析するために、調整項目 の分類を行なった (表 2 )。推進委員会の会議で、MA が提案した設
計案の内容を基に、会議録のセグメント要約から調整内容に該当す るキーフレーズを抽出し、これを性格別に区分し、名称を付けた。 調整項目は「コンセプト」、「空間構成」、「デザイン」、「材料」、「構 造・性能」の 5 つに分類した。注 12) 10) 11)。

表 1 設計対象の分類注 ${ }^{13)}$

\begin{tabular}{|c|c|c|}
\hline 分類 & \begin{tabular}{|c|}
$\begin{array}{c}\text { 本論での } \\
\text { 分類 }\end{array}$ \\
\end{tabular} & 設計要素 \\
\hline 歩道舗装計画 & $\begin{array}{l}\text { 歩道 } \\
\text { 舗装 }\end{array}$ & 舖装材（合成木材、長臺石）、平面線形、幅員構成 \\
\hline \multirow[t]{4}{*}{ 空間計画 } & $\begin{array}{l}\text { 横断 } \\
\text { 歩道 }\end{array}$ & 国債報償路の横断歩道*（韓一劇場前、図 1 の位置を参考） \\
\hline & 露店 & 露店撤去 \\
\hline & 広場 & 東城路マダン、新東将台マダン、北将台マダン \\
\hline & 建築物 & 北将台マダン舞台*、新東将台タワー*、街博物館* \\
\hline 造園計画 & 街路樹 & 植栽、植栽形式、植栽樹類 \\
\hline サイン計画 & サイン & 案内サイン、標識サイン \\
\hline 施設物計画 & 施設物 & ごみ箱、ベンチ、街灯、照明、噴水*、 \\
\hline
\end{tabular}

*は実行されてない設計内容。

\section{表 2 調整項目の区分}

\begin{tabular}{|c|c|c|}
\hline 調整項目 & 定義 & キーフレーズ \\
\hline (A)コンセプト & $\begin{array}{l}\text { 事業の内容と目的、実現方法や } \\
\text { 形態、イメージの概念に対する } \\
\text { 考えや見解 }\end{array}$ & $\begin{array}{l}\text { 東城路のアイデンティティ、 } \\
\text { 東城路だけの〜、東城路の歴史 } \\
\text { 性、ウプソン(邑城)街の象徴、 } \\
\text { 城壁の跡を連結（横断歩道の実 } \\
\text { 行)、街路の活性化のために、 } \\
\text { 公営露店 }\end{array}$ \\
\hline B)空間構成 & $\begin{array}{l}\text { 空間を構成する点、線、面など } \\
\text { の造形的な要素と位置、範囲、 } \\
\text { 空間計画に関する内容 }\end{array}$ & $\begin{array}{l}\text { 露店の撤去、広場位置、広場の } \\
\text { 追加造成、横断歩道の設置、新 } \\
\text { 東将台タワーの建立、施設物設 } \\
\text { 置、植栽(位置)、サイン設置 }\end{array}$ \\
\hline (C)゙ザイン & $\begin{array}{l}\text { 幅、高さ、大きさと形態に関す } \\
\text { る意匠表現及び色の表現で現 } \\
\text { れる特性 }\end{array}$ & $\begin{array}{l}\text { 広場デザイン、舗装デザイン、 } \\
\text { 植栽樹種選定、植栽形式、標諳 } \\
\text { デザイン、夜間照明の計画、施 } \\
\text { 誩物デザイン、、イン計画 }\end{array}$ \\
\hline (D)材料 & $\begin{array}{l}\text { 舗装材の種類、材料の表面性 } \\
\text { 質、仕上げなどを示す内容 } \\
\end{array}$ & $\begin{array}{l}\text { 舖装材料（合成木材、長臺石）、 } \\
\text { 舗装仕上げ }\end{array}$ \\
\hline (E)構造 - 性能 & $\begin{array}{l}\text { 機能に対する能力の程度で、構 } \\
\text { 造、強度、排水のような技術的 } \\
\text { な内容 }\end{array}$ & $\begin{array}{l}\text { 确度および而久性、合成木材デ } \\
\text { ッキの排水、合成木材デッキの } \\
\text { 構造、安全性、舗装施工法、排 } \\
\text { 水工法 }\end{array}$ \\
\hline
\end{tabular}

\section{4-4. 調整行為の 9 種類}

まず、協議内容に対する参加主体間の調整行為を分析するために、 既往研究で示されている調整行為の項目を捉えた。

北尾 (1998) は調整内容に対する MA の調整行為を「肯定評価」、「否 定評価」、「設計目標の提示」、「設計内容の提示」、「設計の実施方法 の提示」、「設計の参考情報の提示」、「意向を確認する」に分けた。 また、服部 (2012) は会議において当事者が相手方に対して「説明」、 「依頼」、「提案」を行う行為を主体的行為として判断した。

以上を踏まえて、調整行為を大きく同意、反対、提議、確認に区 分し、コーディングのセグメント要約内容からその行為と関連寸る キーフレーズ表現を分類し、表 3 のように分けた。詳細に見ると、 9 つの種類に分けられ「同意」、「反対」、「問題指摘」、「提案」、「助 言」、「説明」、「要請」、「質問」、「意図確認」に区分した。

\section{4-5. 協議内容の可視化方法}

本論では、マスタープランの策定までの協議プロセスを分析する ために、設計対象別に協議内容を可視化する方法を提案する。

それぞれの設計対象がどのような主体によって、意見の調整を経 て、合意に至ったのかを示寸ために、調整の方向を持つ対人調整行 
表 3 調整行為の種類注 14

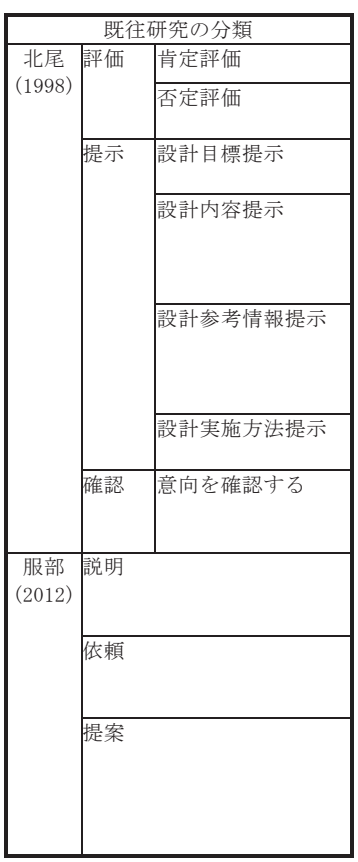

\begin{tabular}{|c|c|c|c|c|}
\hline \multicolumn{2}{|c|}{ 調整行為 } & 定義 & 行為の内容 & キーフレーズでの表現例 \\
\hline \multicolumn{2}{|c|}{ (a)同意 } & 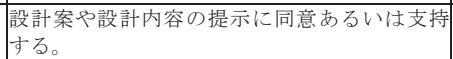 & ・提示された設計案に良い、正しいと判断 & $\begin{array}{l}\text { 「〜に譛成する」 } \\
\text { 「〜绥当」 }\end{array}$ \\
\hline \multicolumn{2}{|c|}{ (b)反対 } & \begin{tabular}{|l} 
提示された設計案に拒否や、相異なる設計の代 \\
案を提示する。
\end{tabular} & \begin{tabular}{|l} 
設計案に拒否意思を表示 \\
·相反する設計内容を提示
\end{tabular} & $\begin{array}{l}\text { 「〜に反対する」 } \\
\text { 「〜は过適切だ」 }\end{array}$ \\
\hline \multirow[t]{5}{*}{\begin{tabular}{|l} 
提 \\
示
\end{tabular}} & $\begin{array}{c}\text { C問題 } \\
\text { 指摘 }\end{array}$ & 設計の問題点や現況に関する問題を提示する。 & $\begin{array}{l}\cdot \text { 現状に対する問題提起 } \\
\cdot \text { 設計に対すする問題点提起 } \\
\cdot \text { 塞行に困難を提起 }\end{array}$ & 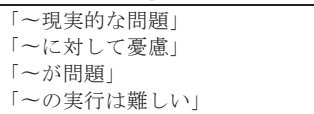 \\
\hline & (d)提案 & $\begin{array}{l}\text { 設計晏と計画を提案し、設計の方向性、期待す } \\
\text { る設十内計容を提示する。 }\end{array}$ & \begin{tabular}{|l}
$\cdot$ 計画を提案 \\
$\cdot$ ·設計の代案を提示 \\
$\cdot$ 事業方向の提示 \\
$\cdot$ 希望する設計表現を提示 \\
\end{tabular} & 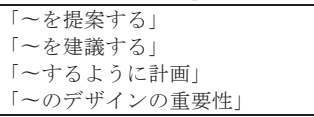 \\
\hline & (e)助言 & \begin{tabular}{|l|} 
設計に参考になる情報や、具体的な穾行方法を \\
提示寸る。
\end{tabular} & $\begin{array}{l}\cdot \text { ·設計情報の提示 } \\
\text { ·設計、実行手法のアドバイス }\end{array}$ & $\begin{array}{l}\text { 「〜が可能だ」 } \\
\Gamma \text { をを進める」 }\end{array}$ \\
\hline & (†)説明 & \begin{tabular}{|l|} 
設計に関する内容を理解させ、従うようにす \\
る。
\end{tabular} & \begin{tabular}{|l}
-設計内容説明 \\
·現状説明 \\
·立場説明
\end{tabular} & $\begin{array}{l}\text { 「〜を説明する」 } \\
\text { 「〜する予定だ」 } \\
\text { 「〜の状況だ」 }\end{array}$ \\
\hline & (9)要請 & 必要な設計や実施のための行動を求める。 & $\begin{array}{l}\cdot \text { デザインの要請 } \\
\cdot \text { ·代案の要請 } \\
\cdot \text { 支援の要請 }\end{array}$ & $\begin{array}{l}\text { 「〜に表現してください」 } \\
\lceil\sim の \text { 代案が必要」 } \\
\text { 「〜の協力要請」 }\end{array}$ \\
\hline \multirow[t]{2}{*}{$\begin{array}{c}\text { 確 } \\
\text { 認 }\end{array}$} & (1)質問 & 設計内容や問題に対して確認する。 & \begin{tabular}{|l}
$\cdot$ ·問題質問 \\
·設計内容質問 \\
·設計情報質問
\end{tabular} & $\begin{array}{l}\text { 「〜の問題に関する質問」 } \\
\text { 〜 に閏する質問」 } \\
\text { 〜の進行質疑」 }\end{array}$ \\
\hline & $\begin{array}{l}\text { (1)竟図 } \\
\text { 確認 }\end{array}$ & 相手が意図する計画や調整の内容を確認する。 & $\begin{array}{l}\cdot \text { ·設計の調慗内容を再確認 } \\
\text { ·事業の目的を確認 } \\
\text { ·志向する計画を碓認 } \\
\text { - 必要な検討事項碓認 } \\
\text { - 議決した計画内容を認定 }\end{array}$ & $\begin{array}{l}\text { 「〜の必要性再確認」 } \\
\lceil 〜 \text { を認識する」 } \\
\lceil 〜 \text { は理解する」 } \\
\text { 〜〜を認定する」 } \\
\text { 〜決定する」 }\end{array}$ \\
\hline
\end{tabular}

為に基づいて、先行話者と後続話者間の調整行為とその方向を可視 化し、協議プロセスを説明できる一つの仕組みを提供する ${ }^{12)}$ 。

まず、会議録の文章セグメント要約内容により、設計対象別に先 行話者と後続話者の発言内容を談話セグメント注 15) 13) に区分し、先 行話者と後続話者を記号で表示した。さらに、先行話者と後続話者 の間に発意を示す直線を描き、調整の方向を矢印で示し、その調整 行為を矢印の上に記号で示した。これにより設計対象による意見調 整の推移を可視化することができる。

その後、可視化した意見調整の推移を基に、各計画内容の討議每 に集約して模式化を行った。MA を中心に円を描き、その線上には 推進委員を、点線の四角には行政を置いた。そして、発言者を把握 し、発言がない参加者はダイヤグラムから除いて、参加主体間の調 整行為とその対応方向を矢印で表した。矢印は調整行為の種類を基 に大きく同意、反対、提示、確認に区分し、矢印の方向は先行話者 に対する後続話者の調整の方向を基準として討議の模式化を行った。

\section{4-6. 小結}

事業の会議録を基に、各設計対象に関する先行話者と後続話者の 発言内容により調整行為とその方向を可視化し、このような協議内 容を集約した上で、討議の模式化ができた。

\section{5.マスタープランの策定に向けた合意形成プロセス}

\section{5-1. マ、スタープランの策定段階における意見調整の推移}

図 7 は、マスタープランの策定に向けた各会議の協議内容を先行 話者に対して後続話者がどのように調整を行ったかを可視化し、こ れを用いて意見調整の推移を分析する。

意見調整の全体を調べると、推進委員会の会議 9 回のうち、設計 の調整に関する討議が 28 件、発意が 368 件であった。その中で、 第 2 段階のマスタープラン検討及び承認段階は約 $39.9 \%$ と最も発意 が集中しており、第 3 段階のマスタープラン変更及び承認は、約 $34.2 \%$ 、第 1 段階の整備事業構想は $19.8 \%$ 、第 4 段階のマスタープ
[会議録のコーディング］

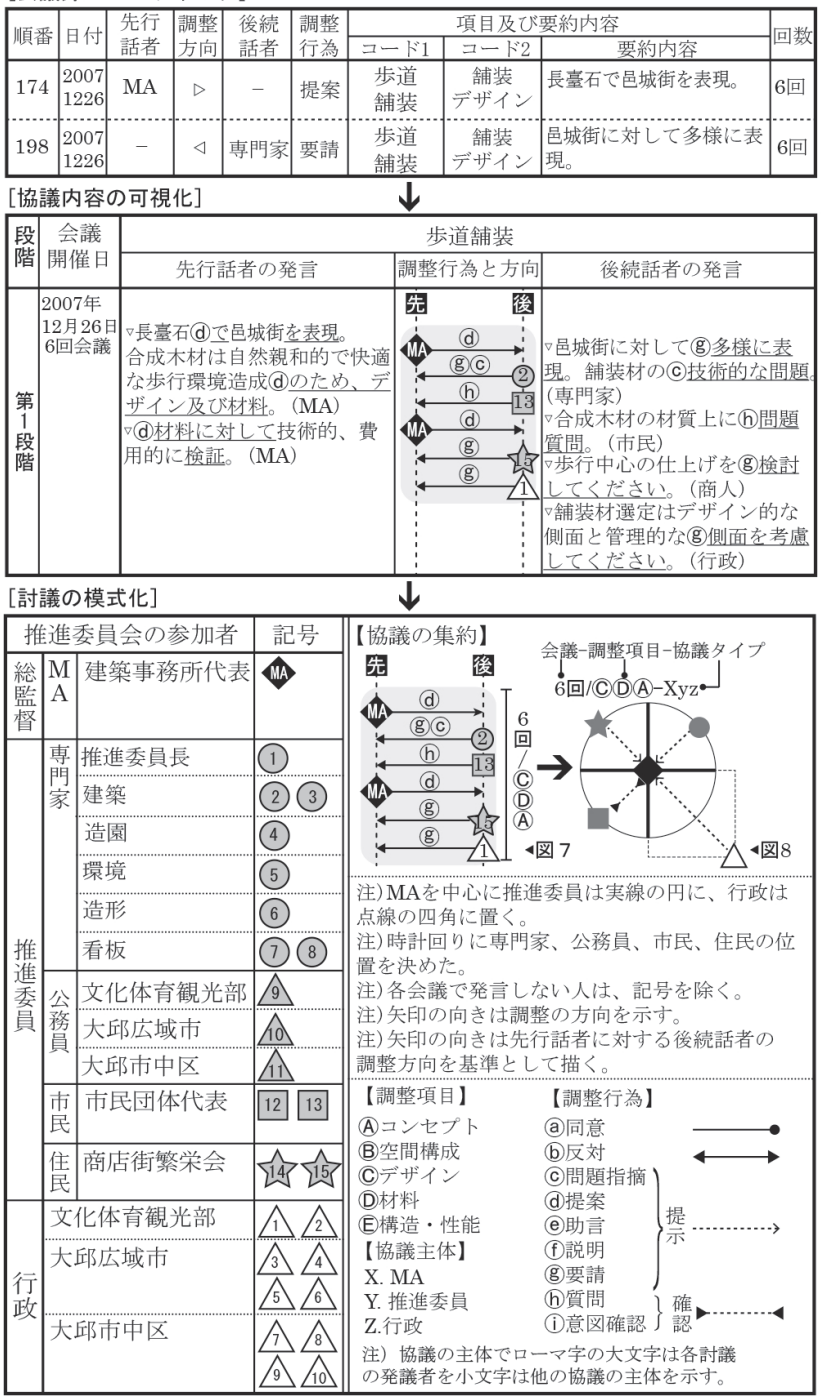

図 6 協議内容の可視化方法注 ${ }^{16)}$ 
ランの完成は $6.5 \%$ であた注 ${ }^{17)}$ 。

・第 1 段階 : 整備事業の構想

第 1 段階の整備事業構想では、推進委員会の会議 2 回の中で 8 件 の討議が行われ、73 件の発意があった。(A)ンセプト $(4$ 件)、(B)空 間構成 $(2$ 件)、(C)デザイン (4 件)、(D)材料(1 件)に関する討議が行われ た。主にコンセプトとデザインに対して意見を調整した。この段階 では、各討議の中で、MA の発議開始が 6 件と最も多く、公務員に よるものが 2 件であった。

談話セグメントで見ると、73 件の発意のうち、露店に関する発意 が 26 件と最多で、そのうち専門家(27 件)と MA(18 件)を中心に意 見調整が行われた。また、調整行為を見ると、( 明(14 件)、 (C)問題指摘(11 件)を中心に協議が進められた。

・第 2 段階：マスタープラン検討及び一部の承認

第 2 段階のマスタープラン検討及び一部の承認段階では、推進委 員会の会議 3 回の中で 10 件の討議が行われ、147 件の発意があつ た。(B)空間構成 (5 件)、(C)デザイン (3 件)、(D)材料(3 件)、 E)構造・性 能(2 件)について討議が行われ、大部分の計画において、空間構成に 関する議論が行われた。この段階では、MAの発議開始が 4 件、専 門家や公務員によるものが 2 件、その他商人、行政で各 1 件であつ た。

147 件の発意のうち歩道舗装に関する発意が 66 件と最も多く、 そのうち専門家 $(45$ 件)、MA(32 件)、公務員 (31 件)、を中心に協議 が行われた。主に(f)説明(42 件)、@提案(38 件)、(C)問題提起(16 件) による調整行為を通じて協議が行われた。

・第 3 段階：マスタープラン変更及び承認

第 3 段階のマスタープランの変更及び承認段階では、推進委員会 の会議 3 回の中で 8 件の討議が行われ、126 件の発意があった。(B) 空間構成(3 件)、(C)デザイン (4 件)、(D)材料(1 件)に対する協議が行わ れ、デザインに関する意見調整が主となった。この段階では公務員 の発議が 3 件、専門家によるものが 2 件、行政は 2 件、商人は 1 件 であった。

126 件の発意のうち、横断歩道に関する発意が 67 件で最も多く、 そのうち専門家 $(53$ 件)、公務員 $(18$ 件)、市民(17 件)を中心に協議が 行われた。調整行為は@提案(50 件)、(f)説明(35 件)、(問題指摘(9 件)、(助言 $(9$ 件)であった。

・第 4 段階：マスタープランの完成

第 4 段階のマスタープランの完成段階では、推進委員会の会議 1 回の中で施設物とサインの囚空間構成の討議が行われ、24 件の発意 があった。専門家による発議開始が 2 件で、そのうち、公務員の発 意が 7 件、専門家や市民の発意が 6 件で、@提案(9 件)、丹説明(6 件)、（）同意(4 件)による調整行為を中心に協議が行われた。

\section{5-2. 協議類型の定義}

図 8 は、各設計対象の協議内容を集約した模式化を通じて、マス タープランの策定までの議論展開過程を示している。また、マスタ ープランの策定に向けた意見調整の推移(図 7 )を踏まえ、発議者と 協議の主体、その調整の方向に着目し、協議の類型化を行い、討議 の模式化をその類型別に分類した。各討議の発議者はX.MA、Y. 推 進委員、Z.行政の 3 つに分類し、それらの発議開始から、他の協議 主体 $(\mathrm{x} . \mathrm{MA} 、 \mathrm{y}$. 推進委員、z. 行政)との調整の型を大きく MA の発 議に対する協議、推進委員の発議に対する協議、行政の発議に対す
る協議に区分され、全 8 つタイプに類型化することが出来る。

（1） MA の発議に対する協議

Xy. MA 中心型(7 件)

MA の発議に対して、推進委員が MA に意見を提示し、MA と意 見を交換するタイプである。図 8 において、真ん中にある MA に対 して円側の推進委員から矢印が向いている。

Xyz. MA 媒介型(4 件)

MA の発議開始で協議が行われ、MA が推進委員と行政の間で意 見を受け入れて確認するタイプである。眓 8 において、MA に対し て円上の推進委員と外側の四角に置かれた行政が、意見の提示とや り取りを行われている。

（2）推進委員の発議に対する協議

Yxz. 推進委員媒介型 $(2$ 件)

推進委員の発議開始で協議が行われ、推進委員が MA と行政との 間で意見を受け入れ、やり取りするタイプである。図 8 において、 円上の公務員を中心に矢印が向いていって、円上の専門家と公務員 が真ん中の MA、外側の行政とやり取りを行われている。

Yx. 推進委員、MA 調整型(3 件)

推進委員の発議開始で協議が行われ、推進委員が MA に意見を提 示し、MA がこれに対応するタイプである。図 8 において、円上の 専門家と公務員が真ん中にある MA と意見を交換し、真ん中の MA と円上の公務員が専門家に向いて意見を提示している。

Yz. 推進委員、行政調整型 (9 件)

推進委員の発議開始で協議が行われ、推進委員に対して行政が意 見を提示し、推進委員の間に意見を提示し、やり取りするタイプで ある。図 8 において、円上の公務員を中心に矢印が集まり、提示さ れるもの、または円上の専門家に矢印が集まっている。

Y. 推進委員内部の調整型 $(2$ 件 $)$

推進委員の発議に対して、推進委員同士で意見を提示し、やり取 りするタイプである。図 8 において、円上の推進委員の内部で、公 務員に対して、専門家と市民が調整を行っている。

(3) 行政の発議に対する協議

Zx. 行政中心型(1 件)

行政の発議に対して、MA が意見を提示して対応するタイプであ る。図 8 において、外側にある行政に対して真ん中にある MA が意 見を提示している。

Zy. 行政、推進委員調整型(2 件)

行政の発議に対して、推進委員が意見を提示し、行政と意見を交 換するタイプである。図 8 において、円上の専門家を中心に意見が 集まって、専門家と外側にある行政が意見を交換している。

\section{5-3．ママスタープランの策定に向けた議論の展開過程}

次に、マスタープランの策定に向けた議論の展開過程をマスター プランの段階と協議の類型によって分析する。

まず、第 1 段階の整備事業構想段階では、4 回の露店に関して、 推進委員の発議に対する Yz. 推進委員・行政調整型で協議が行われ た $(1$ 件)。続いて、6 回の会議では、 7 件の討議のうち、MA の発議 に対する Xyz. MA 媒介型の協議が、露店、歩道舗装であった $(2$ 件)。また、Xy. MA 中心型の協議が、広場、施設物、サインで行わ れた (4 件)。一方、推進委員の発議の開始で、Yxz. 推進委員媒介型 の協議が、横断歩道において行われた $(1$ 件 $)$ 。 


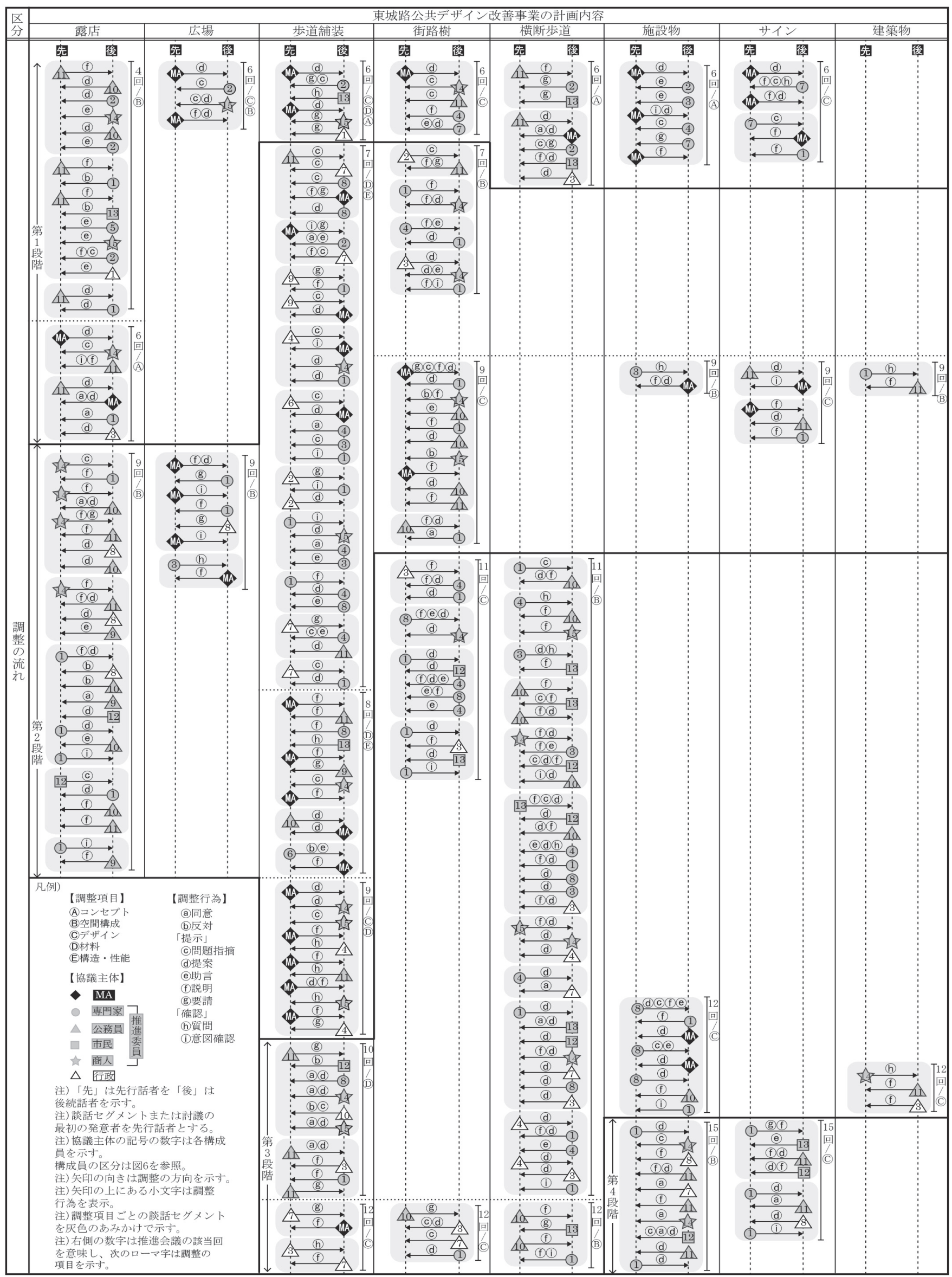

図 7 マスタープランの策定に向けた意見調整の推移 
次に、第 2 段階のマスタープラン検討及び一部の承認段階では、 7 回の会議で 2 件の討議があり、歩道において推進委員の発議によ るYxz. 推進委員媒介型の協議が行われ、街路樹に関して、行政の発 議による Zy. 行政・推進委員調整型の協議が行われた。さらに、8 回の会議では、歩道舗装においてXy. MA 中心型の調整が行われた。 以後、9 回の会議では、 7 件の討議のうち、推進議員の発議に対す る Yz. 推進委員・行政調整型の協議が露店で行われ(1 件)、Yx. 推進 委員・MA 調整型の協議が、施設物やサインで行われた $(2$ 件 $)$ 。また、 Y. 推進委員内部調整型の協議が建築物であった $(1$ 件 $)$ 。一方、MA の発議に対する協議は 3 件で、Xyz. MA 媒介型の協議が広場と歩道 舗装に関して行われ、Xy. MA 中心型の協議が街路樹であった。

続いて、第 3 段階のマスタープラン変更及び承認段階では、10 回 の歩道舗装に関して、推進委員の発議に対する Yz. 推進委員・行政 調整型の協議があった。以降、11 回の会議では、 2 件の討議のうち、 街路樹に関して、行政の発議の開始で Zy. 行政・推進委員調整型の 協議が、横断歩道では、推進議員の発議に対する Yz. 推進委員・行 政調整型の協議が行われた。12 回の会議では、 5 件の討議のうち、 行政の発議による協議が、歩道舗装で Zx. 行政中心型で行い、他の 4 件は推進委員の発議により、Yz. 推進委員・行政調整型の協議が街 路樹と建築物であった $(2$ 件 $)$ 。横断歩道は $\mathrm{Y}$. 推進委員内部調整型の 協議が、施設物では、Yx. 推進委員・MA 調整型の協議が行われた(1 件)。

最後に、第 4 段階のマスタープランの完成段階では、 2 件の討議 が推進委員の発議の開始で行われ、15回の施設物やサインに関して Yz. 推進委員・行政調整型の協議が行われた。

\section{5-4．マスタープランの策定に向けた主体間関係の特性}

マスタープランの策定段階における計画内容毎の討議のダイヤグ ラムを積み重礼て、主体間の関係を見ると、以下のように整理でき る。

露店の場合、第 1 段階の 4 回の会議では、公務員を中心に行われ た議論が、以降 6 回の会議では、MA と公務員が主に意見交換する 方式で進められ、第 2 段階の 9 回の会議では、専門家に対する市民 と公務員の意見交換と商人に対する公務員の意見提示で合意に達し た。

広場において、第 1 段階の 6 回の会議では、MA を中心に協議が 行われ、以後の第 2 段階の 9 回の会議では、MA に対する専門家と 行政の意見交換を通じて合意に達した。

歩道舗装の場合、第 1 段階の 6 回の会議では、MA を中心に行わ れた協議が、第 2 段階の 7 回の会議では、専門家と公務員が MA と 行政との間で意見を交換する方式で行われた。続いて、8 回の会議 では、MA を中心に意見提示や確認が行われ、その後に 9 回の会議 では、MAに対して、専門家と行政が主に確認を行った。第 3 段階 に 10 回の会議では、推進委員の公務員を中心に意見が収容され、 以後、12 回の会議では、MA が行政に意見を提示して合意に到達し た。

街路樹において、第 1 段階の 6 回の会議では、MA に対する推進 委員の意見提示が行われ、第 2 段階の 7 回の会議では、行政を中心 に意見提示と確認が行われた。続いて、9 回の会議では、再び MA を中心に協議が行われた。第 3 段階の 11 回の会議では、専門家に 対する意見提示と意見交換が主に行われ、12 回の会議は公務員を中
心に意見が収容されて協議がまとめられた。

横断歩道の場合、第 1 段階の 6 回の会議では、公務員を中心に協 議が行われ、以後、第 3 段階の 11 回の会議では、主に専門家が意 見を受け入れ、市民が意見を提示して合意がなされた。以降、12 回 の会議は再び専門家と市民が行政に意見提示や確認を行って、協議 がまとめられた。

施設物において、第 1 段階の 6 回会議では、専門家が MA に意見 を提示する方式で行われ、第 2 段階の 9 回の会議では、MA が専門 家に意見を提示し、確認して協議が行われた。第 3 段階の 12 回の 会議では、専門家を中心に意見が提示され、計画の一部が合意に至 つて、第 4 段階の 15 回の会議では、専門家を中心に意見が集約さ れ、施設物の一部の要素が合意された。

サインは、第 1 段階の 6 回の会議で、MA と専門家の意見交換を 通じて協議が行われ、第 2 段階の 9 回の会議では、MA に意見を提 示し、確認する方式で協議が行われた。以後の第 4 段階の 15 回の 会議では、専門家を中心に協議が行われ、一部の計画が合意に達し た。

建築物において、第 9 回の会議で、行政が専門家に意見を提示し、 専門家と確認を通じて協議を行い、以後の第 3 段階の 12 回の会議 では、商人に対して公務員と、行政が意見を提示して合意がなされ た。

\section{5-5. 協議の可視化によるプロセスの総括}

マスタープランの策定段階における計画毎の協議内容を可視化し たことで、マスタープランの策定に向けた議論過程が明らかになっ た。

第一に、整備事業構想段階では MA の提案に、各人が意見を提示 する方式で協議が行われ、その後マスタープラン検討及び一部承認 段階ではMAが媒介になって関係主体らと意見交換や確認を行った。 マスタープラン変更及び承認段階では MA が推進委員に意見を提示 することで協議が行われた。

第二に、各設計対象の主要論点に関する討議の模式化を基に、MA の発議による協議は 2 つの類型に、推進委員の発議による協議は 4 つの類型に、行政の発議による協議は 2 つに類型化された。

第三に、整備事業構想段階では、MA が中心になって議論が広が り、それから徐々に MA と各協議主体が設計内容に応じて、密な議 論が行われ、一部のマスタープランが承認され、マスタープラン変 更及び完成段階では推進委員同士と行政の間での議論になって合意 に至った。

第四に、露店は公務員と商人に対する協議を通じて、歩道舗装は MA と公務員に対する協議を通じて合意がなされ、街路樹は行政と 専門家に対する議論を行い、合意に達した。横断歩道は公務員に対 する協議を行い、その他に広場、施設物、サインは MA や専門家の 協議を通じて、建築物は公務員による協議を進め、合意に至ったこ とが分かった。

第五に、最も長い時間協議が継続された歩道舗装の場合、推進委 員の公務員が主導的に、MA とやり取りし、他の関係者の意見を求 めて、舗装材料の変更が議決された。これで推進委員内部の公務員 が、街路整備事業の推進と変更に大変な影響を及ぼしたことが分か った。 


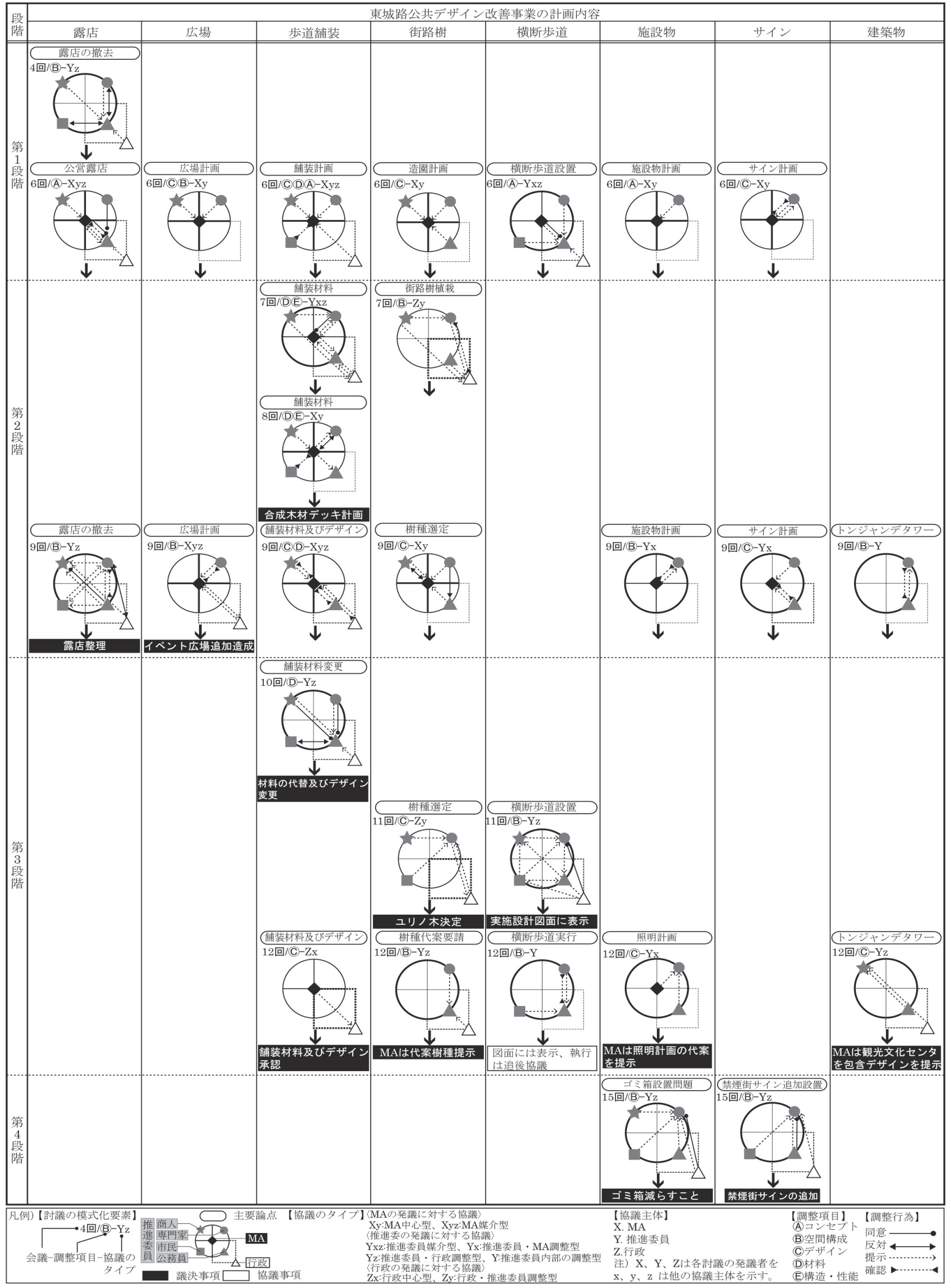

図 8 計画内容毎の議論展開過程 


\section{6. まとめ}

本研究は、街路環境整備事業のマスタープランの策定に向けた協 議過程の可視化を行い、合意形成のための協議の類型と主体間の相 互関係を解明する方法を提示し、具体的な事例の分析を通してその 有効性を示した。

すなわち、会議録のコーディングに基づいた、設計対象別の協議 内容により、先行話者と後続話者の調整行為とその方向を可視化し て集約した討議の模式化を行い、街路環境整備事業のマスタープラ ン策定に向けた協議主体間の対応と相互関係が表現できた。

最後に、本研究で示した協議過程の分析と可視化の方法の活用に 関して付言する。本研究で示した議論分析と可視化の方法は、街路 環境整備事業等の公共空間整備において、最終的な合意形成を共通 理解し事業にフィードバック寸るとともに、その進行過程において、 関係主体による議論の過程を共有し、相互調整を図るためにも有効 であると考える。また、公共空間整備事業の進行過程で起こる問題 を事前に予測し、合意形成を支援するツールとしての可能性が考え られる。

\section{謝辞}

本研究を行うにあたり、早稲田大学の佐藤滋先生の指導を頂 きました。記して感謝の意を表します。

\section{注}

注 1) 韓国は、既存の都市及び住居環境整備法（2003 年）や都市再整備促進の ための特別法（2007 年）の限界を克服し、体系的な都市再生支援のため、 都市再生活性化及び支援に関寸る特別法が 2013 年 6 月に制定された。

注 2) 東城路公共デザイン改善事業におけるマスタープランとは、事業の設計 とその後の付属物を含めて、街路計画全体を決める方針を示し、基本計画 と実施設計が含まれている。本研究では、設計案の策定までを対象とする。

注 3)マスタープランを計画する MA が地域の縁故がない外部専門家であった ため、実務委員会はこの点を補完するために、推進委員の構成員の中から、 専門家と公務員、商店街の住民代表で構成された組織である。MAを助けて 現場で発生した問題を調整し、事業推進を実行していく役を務めた。

注 4) 2008 年、大韓民国公共デザインエキスポの優秀賞受賞。2012 年、第 2 回大韓民国景観大賞の市街地景観最優秀賞。

注 5) 事業範囲は、大邱広域市中区東城路一帯 (大宇ビル〜韓一劇場〜大邱デ パート〜中央治安センター)である。・1 次区間 : 大宇ビル前〜東城 5 街入 口、約 $790 \mathrm{~m}$ (長さ) $\times 12 \mathrm{~m}$ (幅)。・2 次区間 : 東城 5 街入口 中央治安セン夕 一、約 $110 \mathrm{~m}$ (長さ) $\times 12 \mathrm{~m}$ (幅)。マップの出典は 2008 年 6 月 2 日の東城路マ スタープランの報告書、概要による。

注 6) 推進委員に所属された公務員は、文化体育観光部、大邱広域市、大邱市 中区の各代表 3 人で、議決権を持った者である。

注 7) 東城路公共デザイン改善事業報告書の課業遂行及び構成の中で、関係機 関別マスタープランの協議及び調整の推進組織図による。参考文献 7)の pp. 10、また参考文献 8) pp. 212 の事業参与主体の関係構図による。

注 8) 推進委員会の会議録は、推進委員会の実質的な運営を助けする東城路公 共デザイン改善事業の事務局の事務局長と幹事が推進委員会に出席し、現 場で会議の内容を記録した。本論で扱っている会議録は、要約筆記として、 推進委員会の回ごとに開催日時、場所、参加者、主要会議の内容が記載さ れている。

注 9) 3 章は参考文献 7）pp. 12-19、推進委員会の会議録と推進委員会の議決 事項を参照。

注 10)街路整備事業に先立ち、街路を不法占拠していた露店を撤去し、歩行 空間を確保した。この過程で露店商人と行政 (中区庁)の葛藤が発生し、露 店の取り壞しによる露店の生存権保障のデモが行われた。このような問題 を解決するために、行政は合法露店を推進し、東城路の生計型露店対象者 選定のための審議委員会を開催し、生計型露店に対して代替場所の提供と 露店ブースデザインを行い、問題を解決した。事業推進過程の実際は、推 進委員会の会議内容報告書及び通知書、参考文献 5）の pp. 151-152、東城
路公共デザイン改善事業報告書の参考文献 7) pp. 12-19、参考文献 8) の pp. 211 を再構成した。

注 11)質的データは文字テキストを代表とし、人びとの行為や語りに含まれ ている意味の世界を再現する。質的データ分析は単にコーディングによっ てデータの縮約をおこなうだけなく、その一方で、何度となくオリジナル の文脈に立ち帰り、それを参照しながら行為や語りの意味を明らかにする。 参考文献 9)の p. 18、p. 57。

注 12) 北尾は設計の定義から調整対象の内容を分析する指標として「理念」、 「機能・性能」、「空間」、「形態」、「素材」、「その他」の 6 つの調整 項目に分類した。調整項目は文献 11)を参照し、名称を付けた。

注 13) 計画内容の中で北将台マダン舞台、新東将台タワー、街博物館、噴水 は実行できなかった。しかし横断歩道は論議をした後にすぐ実行されず、 長期間の論議を続け、2013 年 3 月に設置された。

注 14) 既往研究は参考文献 3)、10) を参照。

注 15) 談話セグメントとは、談話中のまとまりである。本論では、談話の背 景にある目的に基づいて談話セグメントを定義する。談話セグメントを談 話内の発話や文を用いた行為ととらえる点が特徴である。参考文献 13)の pp. 95 。

注 16) 東城路公共デザイン改善事業に選定された時期に行政自治部（韓国の 中央行政署）の看板整備モデル事業の対象にも選定され、事業間の連携の ための看板推進委員 2 人を推進委員会として迎え入れた。しかし、推進委 員会議での 2 名のうちもう一人の発言は発見されなかったので本分析では 一人だけを含む。

注 17) ・討議：ある問題について検討し、協議する。・協議 : 関係者が個別 にあるいは全体で話し合いを行いながら、集団としての総意を導き出す非 定型的な合意形成の方式。・発意 : 意見を出す行為。・発議 : 会議で討議 する議案 (=提案) を出すこと。

\section{参考文献}

1）高見沢実編著：都市計画の理論，（株)学芸出版社，pp. 267-268，2006. 1

2）北尾靖雅，内井昭蔵，宗本順三：マスターアーキテクト方式によるキャ ンパスデザインの合意形成の研究, 日本建築学会計画系論文集, 第 515 号, pp. 165-172, 1999. 1

3）服部邦比古，阿部浩和：民間都市再生事業の都市計画決定段階における 官民の合意形成に関寸る考察, 日本建築学会計画系論文集, 第 679 号, pp. 2109-2117, 2012.9

4）島田昭仁，小泉秀樹：まちづくり小集団の討議過程の分析手法に関する 研究について, 日本都市計画学会 都市計画論文集, Vol. 48, No. 3, pp. 249-254, 2013. 10

5) Lee Yoon-kyung: Status of Judgment and Improvement Proposal of Public Design Model City, Report of the Ministry of Culture \& Tourism, pp. 6-9, 2011. 10

6) Lee Jeong-ho: The Culture Industry Needed Understanding that the Process is important as much as the Result, Architectural Institute of Korea, Vol. 53, No. 5, pp. 28-32, 2009. 05

7) Dongseongno Public Design Improvement Project Report, pp. 22-23, 2008.8

8) Lee Jeong-ho, Kim Ju-Hyun, Kim Sang-hee: Analysis of Public Street Project Cases From the Viewpoint of Modern Publiceness, Journal of Architectural Institute of Korea, Vol.28, No. 11, pp. 207-218, 2012. 11

9）佐藤郁哉：質的データ分析法, (株) 新曜社, p. 56, 2011.09

10）北尾靖雅, 内井昭蔵, 宗本順三：マスターアーキテクト方式によるニ ユータウンの協働設計手法の研究, 日本建築学会計画系論文集, 第 512 号, pp. 183-190, 1998. 10

11）日本建築学会編：建築学会用語辞典, 岩波書店, pp. 171-499, 1993.12

12）久保推：言語行為と調整理論, (株)ひつじ書房, pp. 178-182, 2014.02

13）坊農真弓, 高梨克也：多人数インタラクションの分析手法, (株) ホー 么社, p. 95，2009.9 


\section{A METHOD FOR THE VISUALIZATION OF THE DELIBERATIVE PROCESS IN URBAN ENVIRONMENT IMPROVEMENT PROJECT}

Focused on the Dongseong-ro public design improvement project in Dae-gu, Korea

\section{Songyi JEON*}

* Doctoral Course, Grad. Student, Dept. of Architecture, Faculty of Science and Eng., Waseda Univ.

The present study develops a new methodology to visualize the interactions between stakeholders during consensus building processes. The research takes as an example the urban environment improvement master plan consultation process for a commercial street in Dongseong-ro, Dae-gu city, Korea and, based on qualitative coding analysis of the project discussion proceedings, clarifies:

1. The priority and importance of each discussion topic.

2. The various natures of the interactions between participants.

3. The changing roles of each participant along the process.

On that purpose, firstly, the whole proceedings of the project meetings that took place a total of 15 times from July 16, 2007 to April 3, 2009 were studied. The project was divided in 4 stages: Master Plan image, First project design check, Further corrections, and finally, last comments and common agreement.

Secondly, inside each project phase, discussions were classified according to speaker (Master Architect (MA), Expert, Government, heads Citizens, Local Merchants and Government officers), topic of each comment (street features and area aesthetics) and position of the speaker and reactions of other participants (8 types). Based on this points a new methodology for objective visualization of the discussion process was developed.

Finally based on this method, the whole consensus building process was defined and the main points of the discussion and idea adjustments were clarified.

As a result, the following points were clarified:

1. Concerning the evolution of the discussion topics, the research proved that the dimension of the discussion changes. In the first stages, larger issues related to the urban space (plaza, street, etc.) are the center of attention, and gradually the discussion turns to physical elements (trees, street furniture, etc.).

2. In terms of participation during the discussions, the MA is more present and active during the first two design proposal stages. Community groups show more commitment during the project check and modification phases. Governmental officers show more interest in the implementation of the project and during the last stage they try to verify the process with the technicians.

3. With regard to the key roles in the discussion, the leader position changes along the course of discussions: the MA holds the leading position in the initial stages, but then takes the role of coordinator in the last phases of the project.

Finally, this new visualization methodology could be used in other different cases as a tool to evaluate the weak/strong points of past consultation processes. Besides, it can also be useful to anticipate conflict in similar participatory projects. 